\title{
Study of the Wastewater Purifying Performance in the M'Zar Plant of Agadir, Morocco
}

\author{
Hind MOUHANNI ${ }^{1}$, Abdelaziz BENDOU ${ }^{1} \&$ Mustapha HOUARI $^{2}$ \\ ${ }^{1}$ Ecole Nationale de commerce et de Gestion, Agadir \\ ${ }^{2}$ Responsable Biologiste de la RAMSA \\ Correspondence: Hind MOUHANNI, National School of Commerce and Management, Ibn Zohr University, \\ Agadir, Morocco. Tel: 212-668-797-969. E-mail: hmouhanni@yahoo.fr
}

Received: December 14, 2012 Accepted: February 19, 2013 Online Published: May 8, 2013

doi:10.5539/ep.v2n3p20

URL: http://dx.doi.org/10.5539/ep.v2n3p20

\begin{abstract}
In order to preserve the quality of water masses and reduce the deterioration of the natural environment, alternative water supplies should be required. The reuse of treated wastewater seems to be a good alternative in agriculture. Our study focuses on the characterization of the physico-chemical effluents (pH, EC, Turbidity, SS, $\mathrm{COD}$, and $\mathrm{BOD}_{5}$ ) in treated wastewater of $\mathrm{M}^{\prime}$ zar plant in Agadir during one-year cycle. It aimed to study the evolution of these parameters over five years since 2006 in compliance with discharge standards in the natural environment and concerning the safety of water for irrigation. It has been shown that the quality and quantity of wastewater depends essentially on the amount of water consumed by the population, the intensity of industrial activities and tourism according to the seasons. The removal percentage of particulate pollution and oxidizable parameters already mentioned were very satisfactory and range from an average of ( 97 to $99 \%$ ). The rate of the Electrical Conductivity (EC) does not change between input and output of plant. The treated wastewater characterized by a high EC (between 3 and $4 \mathrm{dS} / \mathrm{m}$ ) and it can be a problem for reuse in irrigation.
\end{abstract}

Keywords: waste water, treatment plants, physico-chemical of water, Agadir-Morocco

\section{Introduction}

In Morocco, one of the Mediterranean countries, water resources are limited and unevenly distributed in space and time. The region of Agadir represents one of the most productive agricultural areas of the country. However, it provides a strong expansion of economic, industrial and tourist sectors showing an overexploitation of groundwater. It produces a large volume of rejected wastewater. In addition, due to the combined effect of drought and the increase of irrigated surfaces, water storage has gradually decreased in this region characterized by semi-arid to arid climate. The rainfall scarcity which caused a high water deficit in recent years had serious consequences on the groundwater. Consequently, agriculture in this region might be in jeopardy if no sustainable water management is implemented.

The wastewater volumes in the region are very important and become an alternative solution for irrigation. The wastewater is directly discharged into the marine environment without treatment. This negative effect on the environment together with the human and animal populations imposes the purification. This latter is crucial in order to avoid the water shortage, to ensure the effluent physico-chemical and bacteriological quality and to make them compatible with the WHO guidelines for reuse in agriculture (Mouhanni, Hamdi, Bendou, Cavalli, \& Benzine, 2012; Mouhanni, Bendou, \& Er-Raki, 2011; Bali, Gueddari, \& Bouchtina, 2010; Chang \& Ma, 2012).

In addition to two experimental plants installed at both Bensergao and Drarga communities, there's the plant of the Agadir, located on the big hills of M'zar Ait Melloul and which started in June 2005.

The M'zar plant receives effluents from all Agadir other plants. The total gross volume is $50,000 \mathrm{~m}^{3} /$ day undergoing primary decantation treatment. Only $10000 \mathrm{~m}^{3} /$ day of decanted waters which crosses percolation to the secondary treatment by filtration on beds of sand are finally rejected in the sea. This important volume is a significant loss for the agricultural sector in this semi-arid climate region and it is a water deficit of several years.

In the present study, we evaluated the performance of the water reclamation plant, after we studied the seasonal variations in the physico-chemical properties of wastewater (decanted and filtered) from the M'zar plant during the cycle of a typical year according to the limit discharges of the natural environment and with the irrigation reuse 
(WHO: World Health Organization, FAO: Food and Agriculture Organization) standards.

\section{Materials and Methods}

Our study was conducted in the wastewater plant of M'zar Ait Melloul, it was started up in 2005 under the leadership of RAMSA (Régie Autonome Multiservices d'Agadir; Water Supply Service of Agadir). The treatment process of this plant is the infiltration percolation which is described in the following paragraph.

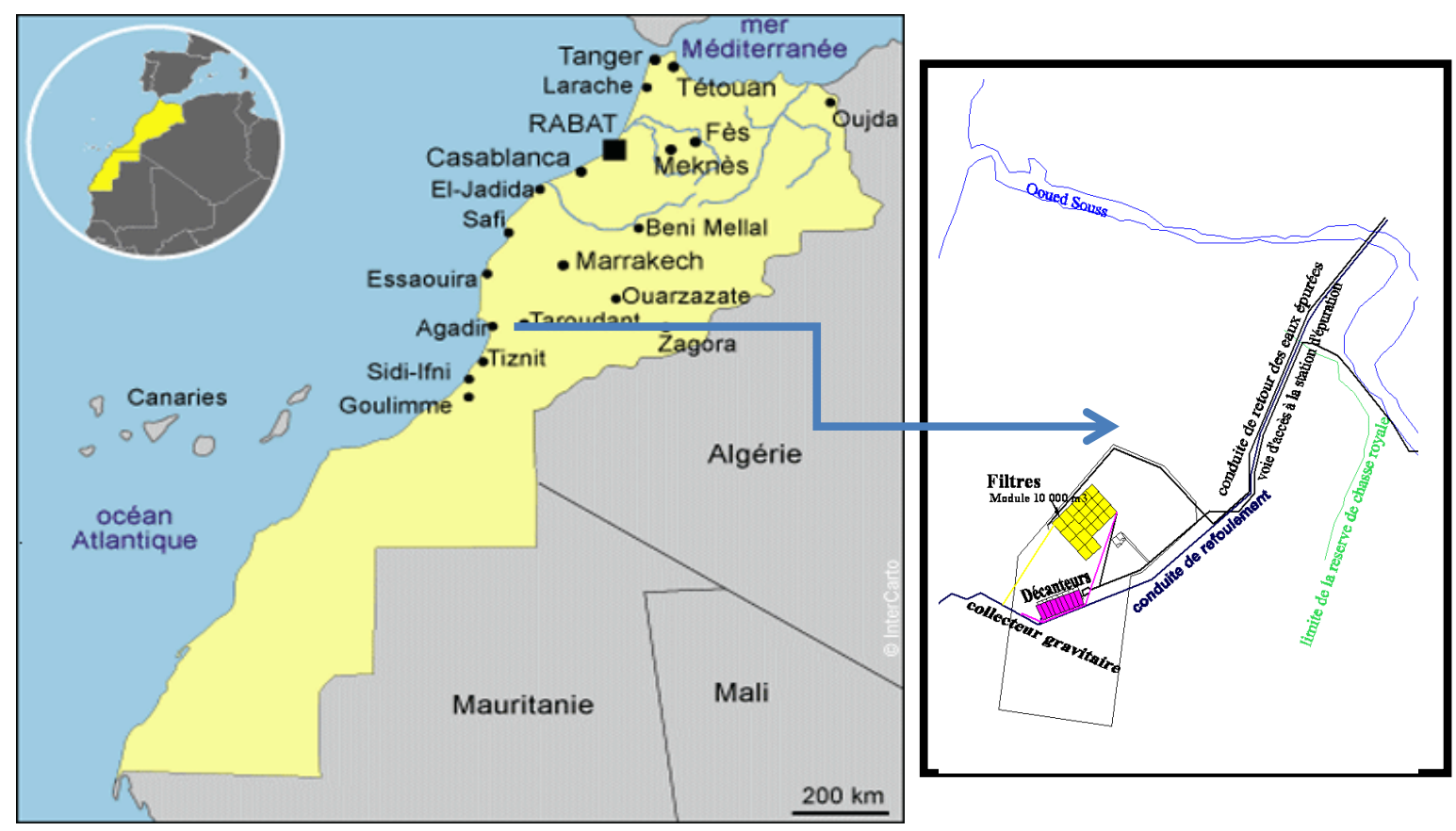

Figure 1. Localization of the M'zar plant of Agadir

\subsection{M'zarPlant Operation Principle}

The site of the wastewater treatment plant is located at $8.5 \mathrm{Km}$ south of the Agadir city on the left bank of Oued Souss. The plant receives a flow of $50,000 \mathrm{~m}^{3} /$ day municipal and industrial wastewater, which is subjected to decantation and percolation infiltration and UV disinfection in the facility.

\section{-Primary treatment: decanting}

Primary treatment consists of settling in 9 decanters with a hydraulic retention time of effluent in the order of 2.5 days. The decantation pools treat the entire inflow to the plant, which is $\left(50,000 \mathrm{~m}^{3} / \mathrm{day}\right)$. However, the pools are deep enough to present a large volume reserved for the storage of mud undergoing anaerobic digestion within the operation. The physical characteristics of the operation are as follows in Figure 2.

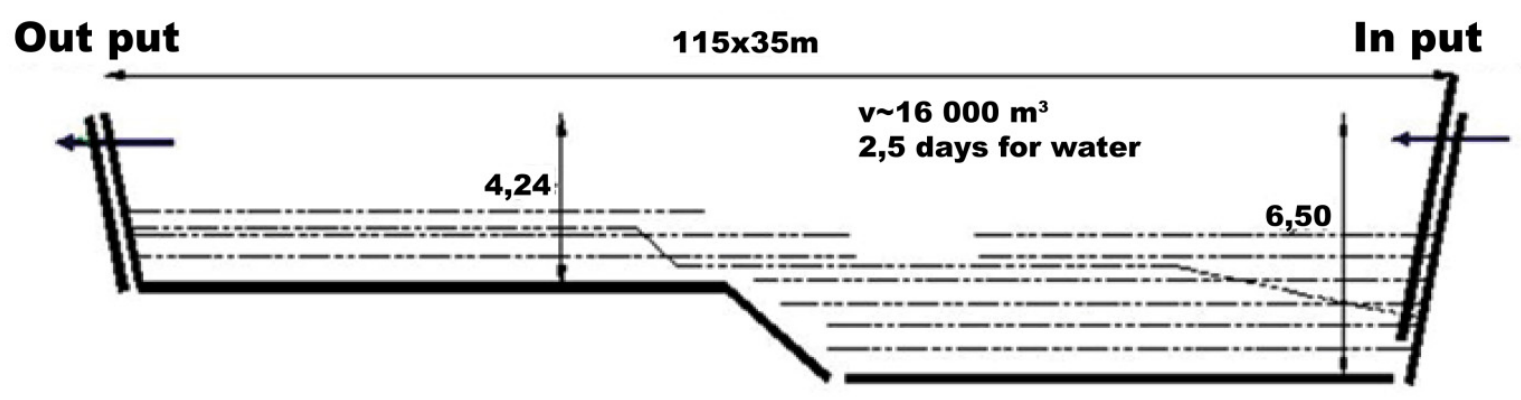

Figure 2. Longitudinal section of a settling pool and the M'zar wastewater treatment plant 


\section{-Secondary treatment operation: sand filters}

The water treatment by infiltration percolation process takes place in 24 filters that have a $10,000 \mathrm{~m}^{3} /$ day capacity to treat. It consists of having waters to percolate slowly through a granular medium in which an unsaturated flow of water is maintained. According to a user sequence input, the water is alternated by periods of supply ( 3 successive days of operation) and idle stage (2 rest days). During this process, different mechanisms are occurring in the granular medium (Autonomous multi service agency of Agadir, 2005) primarily physical retaining almost all of the suspended solids (SS) and larger pathogen micro-organisms (parasites) on the surface.

The surface of each filter is $5000 \mathrm{~m}^{2}$ and has respectively from bottom to top a geotextile protection of a geomembrane, geotextile anti-punching, drain, gravel and sand as shown in Figure 3.

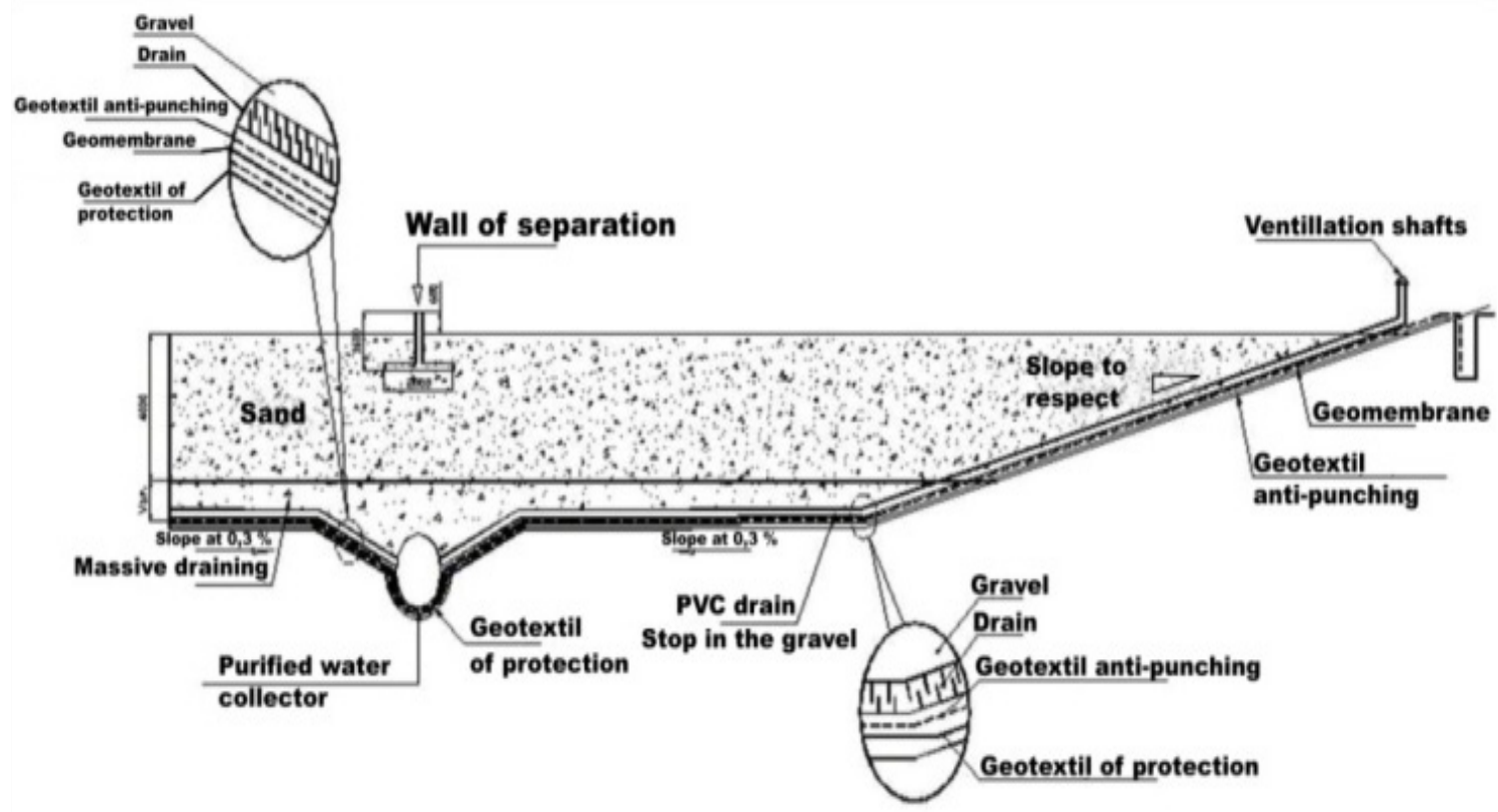

Figure 3. Longitudinal section of a sand filter in the M'zar Plant of Agadir

\subsection{Analytical Methods}

The analytical methods used in the physico-chemicals laboratory are described as follows:

\section{-pH and electrical conductivity}

The $\mathrm{pH}$ and electrical conductivity are measured using a pH meter-type conductivity (WTW 525).

\section{-Suspended solid and turbidity}

TSS are determined according to AFNOR (T90-105). After filtration of a test on filters Whatman GF/C (0.45 mm) previously dried and weighed. The filters were placed in an oven at $105{ }^{\circ} \mathrm{C}$ for 2 hours, weighed to assess the MES. Turbidity was measured by a nephelometric turbidity meter HANNA HI 93703C, it measures the intensity of light deflected at an angle of $90^{\circ}$ to the incident light that passes through the straight sample.

\section{-Biological oxygen demand (BOD)}

It features the biodegradable fraction of organic matter involving bacteria in wastewater. $\mathrm{BOD}_{5}$ measurement is performed on raw samples respirometric method. It was determined using a manometric device (BSB model 602) incubated in a thermostatic chamber at $20^{\circ} \mathrm{C}$ according to the procedure indicative by Rodier (1996).

\section{-Chemical oxygen demand (COD)}

COD was determined according to standard AFNOR T90-10, oxidation of organic matter in the sample was performed by a COD meter type GEBR 14 in the presence of an excess of potassium dichromate, in acid and in the presence of silver sulphate and sulphate of mercury. The excess potassium dichromate is determined by the iron sulphate and ammonium (Mohr salt) in the presence of the colored indicator Feroin, COD was expressed as the 
amount of oxygen from potassium dichromate consumed in the mineralization of organic matter $\left(\mathrm{mg} \mathrm{O}_{2} / \mathrm{l}\right)$.

\section{Plant Purification Performance}

3.1 Flow Evolution, Physical Parameters of Particulate Pollution and Oxidizable in a Five-Year Term 2006-2010

The data in Table 1 reports the annual flow at the entrance and exit in the plant which is less than $50,000 \mathrm{~m}^{3} / \mathrm{day}$ and $10,000 \mathrm{~m}^{3} /$ day which represents the maximum flow of the plant. This implies that the capacity of the plant allows the reception of the total wastewater release of the Agadir city without floods.

Table 1. The plant flow in a five-year term 2006-2010 at the entrance and exit in the plant

\begin{tabular}{cccc}
\hline & \multicolumn{3}{c}{ Flow $\left(\mathbf{m}^{\mathbf{3}} / \mathbf{y e a r}\right)$} \\
\cline { 2 - 4 } Year & Entry & Filtering entry & Output \\
\hline $\mathbf{2 0 0 6}$ & 32152 & 7910 & 9420 \\
$\mathbf{2 0 0 7}$ & 36336 & 9773 & 7874 \\
$\mathbf{2 0 0 8}$ & 40130 & 9971 & 7603 \\
$\mathbf{2 0 0 9}$ & 42483 & 9597 & 7755 \\
$\mathbf{2 0 1 0}$ & 40310 & 9824 & 6999 \\
\hline
\end{tabular}

The follow-up of the physical parameters, the relief parameter rates and particulate oxidizable during the five years since 2006 allows us to consider the changes displayed in Table 2.

Table 2. Annual evolution of $\mathrm{pH}$, Electrical conductivity, suspended solids and organic pollutants during a five year 2006-2010

\begin{tabular}{|c|c|c|c|c|c|}
\hline & & \multicolumn{2}{|c|}{ Wastewater } & \multicolumn{2}{|c|}{ Treated wastewater } \\
\hline Parameters & & $\mathbf{p H}$ & $\mathrm{EC}(\mathrm{dS} / \mathrm{m})$ & pH & $E C(d S / m)$ \\
\hline \multicolumn{2}{|r|}{2006} & 7.19 & 4.01 & 7.28 & 4.05 \\
\hline \multicolumn{2}{|r|}{2007} & 7.29 & 3.60 & 7.44 & 4.13 \\
\hline \multicolumn{2}{|r|}{2008} & 7.49 & 3.60 & 7.55 & 3.60 \\
\hline \multicolumn{2}{|r|}{2009} & 7.46 & 3.70 & 7.34 & 3.47 \\
\hline \multicolumn{2}{|r|}{2010} & 7.52 & 4.05 & 7.52 & 3.60 \\
\hline \multirow[b]{2}{*}{ Parameters } & \multicolumn{5}{|c|}{ Removal percentage (\%) } \\
\hline & Turbidity & SS & COD & \multicolumn{2}{|r|}{ BOD $_{5}$} \\
\hline 2006 & 99.47 & 99.11 & 97.50 & & 99.48 \\
\hline 2007 & 99.48 & 98.15 & 96.41 & & 98.75 \\
\hline 2008 & 99.39 & 98.80 & 96.16 & & 97.03 \\
\hline 2009 & 98.84 & 97.44 & 97.07 & & 97.50 \\
\hline 2010 & 98.69 & 97.49 & 98.12 & & 98.03 \\
\hline
\end{tabular}

Annual average of the $\mathrm{pH}$ and electrical conductivity(EC) did not change between input and output of the plant. This is considers the treated wastewater at the exit station to be characterized by a high EC (between 3 and $4 \mathrm{dS} / \mathrm{m}$ ) on one hand. On the other hand, the particulate pollution rate and oxidizable were very satisfactory and range from an average of (97 to $98 \%$ ) to (98 to $99 \%$ ). The similar result has been shown by Liu et al. (2010), they applied Oyster shell and plastic ball as the media of biological aerated filters (BAF) to treat chemical oxygen demand (COD), ammonia nitrogen $\left(\mathrm{NH}_{3}-\mathrm{N}\right)$ and total phosphorus (TP) from municipal wastewater in two lab scale upflow BAFs. The results indicated that both BAFs had excellent COD and $\mathrm{NH}_{3}-\mathrm{N}$ removal efficiency when HRT was longer than $4 \mathrm{~h}(85.1 \% ; 80.0 \%)$ and $(98.1 \%$; 93.7\%) respectively. However, oyster shell BAF had higher removal efficiency than plastic ball BAF. Arnal et al. (2008) studied ultrafiltration as a pre-treatment of other membrane technologies in the reuse of textile wastewaters. The removal percentage of COD obtained was more than $50 \%$, and it wasn't enough to be directly reuse the permeate in the industry. However, the combined Ultrafiltration (UF) and Nanofiltration (NF) process was more efficient than a process exclusively based on NF.

Therefore, the treatment system of the M'zar plant presents better performance during the first five years 
concerning particulate pollution and oxidizable, which reassures other processes such as disinfection for subsequent possible reuse of treated wastewater from the plant (Hadadin, Qaqish, Akawwi, \& Bdour, 2010).

3.2 The Seasonal Follow-Up of Physical Parameters, the Particulate Pollution and Oxidizable Over A Year Type 2006

\subsubsection{The Flow}

The results of this study focus on the physical and chemical analysis of wastewater, decanted and treated at the plant. We quote the average scores on the seasonal year 2006 which represents the first year of the plant operation Table 3.

Table 3. Daily flow input at the M'zar plant during the seasons of the year 2006

\begin{tabular}{ccccc}
\hline Flow $\left(\mathrm{m}^{3} /\right.$ day $)$ & Winter & Spring & Summer & Autumn \\
\hline Min & 24106 & 21082 & 35769 & 26276 \\
Max & 37065 & 42422 & 44150 & 30013 \\
Average & 30038.25 & 32889.5 & 37946.4 & 28328.25 \\
\hline
\end{tabular}

During 2006, the flow follows an evolutionary trend from winter to summer while it declined in the fall to return a value equivalent to that of winter. This is reflected by a large tourist, industrial and domestic activities in the same region, especially during the summer that exceeds the rate of winter and fall of almost $21 \%$. This figure is used to estimate the intake of this pollutant load flow.

\subsubsection{Physical Parameters}

The $\mathrm{pH}$ and (EC) of the water plant at the input and output are shown in Table 4. The plant waters are generally neutral. This is acceptable according to the Moroccan standard of wastewater quality for irrigation. Similarly, these $\mathrm{pH}$ values range between 6.5 and 8.5 considered limits direct discharges into the receiving environment. Regarding to the (EC) for the two water natures of the plant, it has shown a strong mineralization relatively stable undergoing decantation and infiltration percolation through beds of sand. The (EC) is still outside the Moroccan legal requirements $(2.7 \mathrm{dS} / \mathrm{m}$ for water irrigation and drinking water $)$, which explains that the reduction of this parameter is very low or almost null. This reflects the quality of the drinking water used (EC between 0.6 to 1 $\mathrm{dS} / \mathrm{m}$ ), and the discharges of the industrial and domestic activities in the region.

Table 4. PH and EC of treated water from the M'zar plant during 2006

\begin{tabular}{cccc}
\hline & Parameters & $\mathrm{pH}$ & $\mathrm{EC}(\mathrm{dS} / \mathrm{m})$ at $20{ }^{\circ} \mathrm{C}$ \\
\hline Wastewater & Min & 7.14 & 3.59 \\
& Max & 7.33 & 4.24 \\
& Average & 7.19 & 3.94 \\
& Standard deviation & 0.16 & 0.73 \\
\hline Treated wastewater & Min & 7.18 & 3.53 \\
& Max & 7.40 & 4.16 \\
& Average & 7.14 & 3.59 \\
\hline Limit of direct discharge & $6.5-8.5$ & 0.33 \\
Removal percentage & $0.75 \%$ & 8.00 \\
\hline
\end{tabular}

\subsubsection{Particulate Pollution}

Only the suspended solids (SS) allow quantifying particulate pollution. It represents all the organic and inorganic particles contained in wastewater. Its effect on the physico-chemical characteristics is harmful. The small fraction of SS (colloids) causes turbidity and also a reduction in light penetration. However, a high turbidity indicates the 
presence of (SS). Furthermore, a high turbidity allows micro-organisms to attach to particles, which protects them from the treatment of infiltration percolation. The follow-up of these two parameters in the wastewater of the M'zar plant during the seasons of the year 2006 provided in Table 5.

The concentrations of (SS) and turbidity of wastewater follow the same trend throughout the year except in spring when the turbidity has a sharp increase close to that of summer. Winter and fall keep a constant average rate along the year. Moreover, effluents from M'zar plant reflect an intense particulate pollution, especially during the summer, which is explained by a large hydraulic discharge following because of a huge industrial and domestic activity in the region.

Table 5. Treatment parameters outcome of particulate pollution of M'zar plant during the seasons of the year 2006

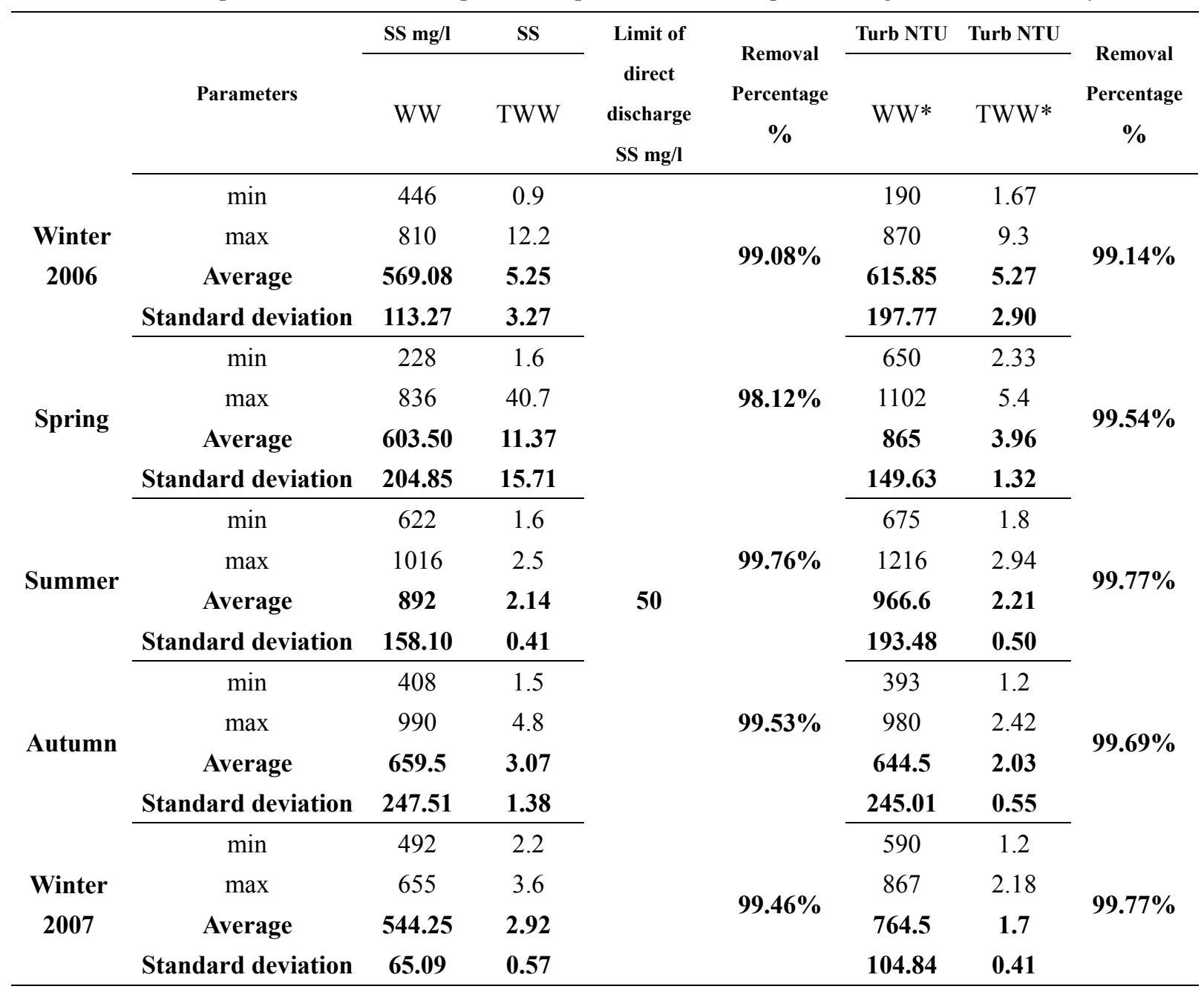

* WW: wastewater; TWW: treated wastewater

The industrial effluents are mainly generated by the food processing factories in the region (fish markets, canned meats and vegetables (Mouhanni, Hamdi, Bendou, Cavalli, \& Benzine, 2012; Mouhanni, Bendou, \& Er-Raki, 2011). The effluents from fish processing plants are loaded with large concentration of biodegradable organic matter, salts and also suspended solids.

In general, the treatment of this pollution appears reliable; its concentrations are below the limit of direct discharge of treated wastewater into the environment according to Moroccan standards (Liu, Yang, Yuan, \& Wu, 2010), as shown in Table 5 with abatement rates which may reach almost $100 \%$.

\subsubsection{Removal of Organic Pollutants}

The result of biological oxygen demand $\left(\mathrm{BOD}_{5}\right)$ and chemical oxygen demand (COD) are related empirically to the oxidizable matter. It designates the organic biodegradable and non-biodegradable and other oxidizable 
substances contained in the effluent (Bali, Gueddari, \& Boukchina, 2010; Al-Hamaiedeh \& Bino, 2010; X. Zhang, Zhao, M. Zhang, \& Wu, 2011). The results of the analysis of these parameters are reported in Table 6 below.

The quality of the water entering the plant is responsible for oxidizable matter during spring and summer, similar to the previous parameters, but during the winter and autumn, the effluent concentrations appear stable by the cold that affects the microbial activity. At the exit, the treated water is received with low concentration of oxidizable material as the curve shows with seasonal concentrations of $\mathrm{COD}$ and the $\mathrm{BOD}_{5}$ respectively lower at 500 and 100 $\mathrm{mg} / \mathrm{l}$ considered as direct discharge limits in nature (Table 6). These results are consistent with those of Bali et al. (2010) which applied intermittently to the secondary effluents, over $100 \mathrm{~m}^{2}$ of infiltration basin, percolated through unsaturated coarse sand. Analyses of the filtered water sampled at 50,100 and $150 \mathrm{~cm}$ bed depths showed that high water temperature improves oxidation efficiency. In summer season, the main water temperature was $25{ }^{\circ} \mathrm{C}$, more than $90 \% \mathrm{COD}$ was removed and more than $94 \% \mathrm{~N}-\mathrm{NH}_{4}$ oxidized. In winter, the mean water temperature was $15{ }^{\circ} \mathrm{C}$, ammonium and COD removals were $81 \%$ and $71 \%$ respectively. Results confirmed that this technique is performed as an advanced treatment system for COD and ammonium (Mouhanni, Bendou, \& Er-raki, 2011; Arnal et al., 2008; Zhao et al., 2012).

Table 6. Treatment parameters Results of M'zar plant oxidizable pollution during the seasons of the year 2006

\begin{tabular}{|c|c|c|c|c|c|c|c|c|c|}
\hline & \multirow[b]{2}{*}{ Parameters } & $\begin{array}{c}\mathrm{COD} \\
\mathrm{mg} \mathrm{O}_{2} / 1\end{array}$ & $\begin{array}{c}\mathrm{COD} \\
\mathrm{mg} \mathrm{O}_{2} / 1\end{array}$ & \multirow{2}{*}{$\begin{array}{c}\text { Limite of } \\
\text { direct } \\
\text { discharg } \\
\text { e mg } \\
\text { COD } \\
\mathrm{O}_{2} / 1\end{array}$} & \multirow{2}{*}{$\begin{array}{c}\begin{array}{c}\text { Removal } \\
\text { percentag } \\
\mathrm{e}\end{array} \\
\\
\%\end{array}$} & \multirow{2}{*}{$\begin{array}{c}\mathrm{BOD}_{5} \\
\mathrm{mg} \mathrm{O}_{2} / 1 \\
\mathrm{WW}^{*}\end{array}$} & \multirow{2}{*}{$\begin{array}{c}\mathrm{BOD}_{5} \\
\mathrm{mg} \mathrm{O}_{2} / 1\end{array}$} & \multirow{2}{*}{$\begin{array}{c}\begin{array}{c}\text { Removal } \\
\text { percentag } \\
\mathrm{e}\end{array} \\
\% \\
\end{array}$} & \multirow{2}{*}{$\begin{array}{c}\text { Limite of } \\
\text { direct } \\
\text { discharge } \\
\mathrm{mg} \\
\mathrm{BOD}_{5} \mathrm{O}_{2} / \\
1\end{array}$} \\
\hline & & WW & TWW & & & & & & \\
\hline \multirow{4}{*}{$\begin{array}{l}\text { Winter } \\
2006\end{array}$} & $\min$ & 1083 & 29 & \multirow{20}{*}{500} & \multirow{4}{*}{$96.90 \%$} & 505 & 1.2 & \multirow{4}{*}{$99.58 \%$} & \multirow{20}{*}{100} \\
\hline & $\max$ & 2410 & 106 & & & 1326 & 6.1 & & \\
\hline & Average & 1646.31 & 50.97 & & & 777.31 & 3.25 & & \\
\hline & $\begin{array}{l}\text { Standard } \\
\text { deviation }\end{array}$ & 381.96 & 22.23 & & & 229.65 & 1.79 & & \\
\hline \multirow{4}{*}{ Spring } & $\min$ & 1252 & 24 & & \multirow{4}{*}{$97.41 \%$} & 531 & 1.35 & \multirow{4}{*}{$99.10 \%$} & \\
\hline & $\max$ & 2842 & 119 & & & 2483 & 49 & & \\
\hline & Average & 2067.33 & 53.5 & & & 1286.83 & 11.64 & & \\
\hline & $\begin{array}{l}\text { Standard } \\
\text { deviation }\end{array}$ & 557.11 & 33.30 & & & 724.02 & 18.63 & & \\
\hline \multirow{4}{*}{ Summer } & $\min$ & 1782 & 24 & & \multirow{4}{*}{$98.55 \%$} & 861 & 1.5 & \multirow{4}{*}{$99.55 \%$} & \\
\hline & $\max$ & 2813 & 42 & & & 1383 & 8.7 & & \\
\hline & Average & 2191.80 & 31.72 & & & 1251 & 5.68 & & \\
\hline & $\begin{array}{l}\text { Standard } \\
\text { deviation }\end{array}$ & 407.84 & 6.55 & & & 345.23 & 2.77 & & \\
\hline \multirow{4}{*}{ Autumn } & $\min$ & 575 & 27 & & \multirow{4}{*}{$98.21 \%$} & 263 & 0.44 & \multirow{4}{*}{$99.86 \%$} & \\
\hline & $\max$ & 2303 & 34 & & & 1771 & 3 & & \\
\hline & Average & 1727.75 & 31 & & & 1070.5 & 1.47 & & \\
\hline & $\begin{array}{l}\text { Standard } \\
\text { deviation } \\
\end{array}$ & 797.60 & 3.16 & & & 618.79 & 1.25 & & \\
\hline \multirow{4}{*}{$\begin{array}{l}\text { Winter } \\
2007\end{array}$} & $\min$ & 1697 & 35 & & \multirow{4}{*}{$94.38 \%$} & 631 & 1.2 & \multirow{4}{*}{$98.93 \%$} & \\
\hline & $\max$ & 1820 & 154 & & & 861 & 19 & & \\
\hline & Average & 1694.5 & 95.25 & & & 787.25 & 8.38 & & \\
\hline & $\begin{array}{l}\text { Standard } \\
\text { deviation }\end{array}$ & 121.51 & 57.65 & & & 92.01 & 7.72 & & \\
\hline
\end{tabular}

* WW: wastewater; TWW: treated wastewater. 
To determine the quality variation of the effluent from the M'zar plant during the seasons of the year 2006, the ratios are on Table 7.

The $\mathrm{COD} / \mathrm{BOD}_{5}$ ratio is about 2.15 in winter (2006 and 2007) as the maximum value of a typical domestic effluent in the meantime when spring and summer have ratios between 1.6 and 1.8 indicating a good biodegradability of this pollution. This ratio remains within the normal range between 1 and 3 in the majority of fish processing industries that RAMSA (Régie Autonome Multiservices d'Agadir; Water Supply Service of Agadir) conducted a similar study to characterize the industrial effluents of plant. So these results are attributed to heterogeneous effluents. The $\mathrm{SS} / \mathrm{BOD}_{5}$ ratio is at the average of 0.64 in 2006. It confirms the organic effluent and information on the production of sludge (Quevedo, Sanz, Lobo, Temprano, \& Tejero, 2012).

Table 7. The ratios of the global parameters of the M'zar plant wastewater pollution

\begin{tabular}{lccc}
\hline \multicolumn{1}{c}{ Season } & ${\mathrm{COD} / \mathrm{BOD}_{5}}_{5}$ & $\mathrm{SS}^{\mathrm{B}} \mathrm{BOD}_{5}$ & Oxydizable material $(\mathrm{mg} / \mathrm{l})$ \\
\hline Winter 2006 & 2.1 & 0.73 & 19.16 \\
Spring 2006 & 1.6 & 0.47 & 25.59 \\
Summer 2006 & 1.8 & 0.71 & 14.36 \\
Autumn 2006 & 1.6 & 0.62 & 11.31 \\
Winter 2007 & 2.15 & 0.69 & 37.34 \\
\hline
\end{tabular}

In conclusion, the variability of ratios converges toward the information that there's an easily degradable oxidizable material despite its heterogeneity, which ensures the presence of industrial effluent other than domestic (Arnal et al., 2008; Zhao et al., 2012).

\subsubsection{The Physico-Chemical Industrial Effluent Discharges in the Region}

The measurements of some physico-chemical industries connected to the collecting pipe of the M'zarplant bring us the following results presented in Table 8 . According to this table, there is a hypersaline flux, rich in organic matter but keep the ratio $\mathrm{COD} / \mathrm{BOD}_{5}$ between 1 and 3 , indicating the biodegradability of the effluent despite is high even considering the high saline concentration ofsome industrial streams. Industrial activity is a source of salinity in the treated wastewater because of the contribution of brine in the different steps of the fish transformation process. This is judged by a very high EC and very amplified concentrations of chlorides.

Table 8 . The pollution parameters results of the physical-chemical industrial discharges during 2006

\begin{tabular}{lccccccc}
\hline & $\mathbf{p H}$ & $\begin{array}{c}\mathbf{E C} \\
(\mathrm{dS} / \mathrm{m})\end{array}$ & $\begin{array}{c}\mathbf{C l}^{-} \\
(\mathrm{mg} / \mathrm{l})\end{array}$ & $\begin{array}{c}\mathbf{S S} \\
(\mathrm{mg} / \mathrm{l})\end{array}$ & $\begin{array}{c}\mathbf{C O D} \\
(\mathrm{mg} \\
\left.\mathrm{O}_{2} / \mathrm{l}\right)\end{array}$ & $\begin{array}{c}\mathbf{B O D}_{\mathbf{5}} \\
(\mathrm{mg} \\
\left.\mathrm{O}_{2} / \mathrm{l}\right)\end{array}$ & $\mathbf{C O D}$ \\
\cline { 2 - 7 } Aceiro Maroc & 7.52 & 2.38 & 405 & 518 & 7872 & 6511 & 1.2 \\
Vanelli Maroc & 6.10 & 44.1 & 16842 & 703 & 8685 & 6051 & 1.44 \\
Atlantic conserve & 7.12 & 5.79 & 3755 & 850 & 9984 & 7551 & 1.4 \\
Siallco Tikiouine & 6.38 & 146 & 90256 & 1744 & 24346 & 15176 & 1.6 \\
Douha QI Ait Melloul & 6.05 & 11.48 & 3616 & 592 & 46080 & 25201 & 1.8 \\
Limit indirect discharge & $\mathbf{6 . 5}$ to $\mathbf{9}$ & $\mathbf{2 . 7}$ & $\mathbf{1 0 5 *}$ & $\mathbf{6 0 0}$ & $\mathbf{1 0 0 0}$ & $\mathbf{5 0 0}$ & $\mathbf{1}$ to 3 \\
\hline
\end{tabular}

* Quality standard of waters destined to irrigation

Furthermore, emissions from these factories are overloaded with solids and specifically the scales of fish. The latter has a very slow biodegradability, which implicates the operation of sand filters by increasing the risk of clogging. It also hinders the reuse of sludge/mud from the fact that we find them in all of (SS) decanters.

The plant treats these parameters with a strong manner, even if they exceed the threshold eligibility in terms of 
$\mathrm{COD}, \mathrm{BOD}_{5}$ and (MES) of $300 \%$. Their salinity remains a handicap in the treated wastewater for reuse in agriculture (Hadadin, Qaqish, Akawwi, \& Bdour, 2010; Yi, Jiao, X. Chen, \& W. Chen, 2011).

\section{Conclusion}

The quality and quantity of wastewater that the M'zar plant receives depends essentially on the amount of water consumed by the population. It also depends on the intensity of industrial activities and tourism according to the seasons. This causes fluctuations on the level of physic-chemical pollution degree of effluent along the year.

All the studied parameters, specifically EC, TSS, COD, BOD, and the ratios, indicate that urban wastewater collection network is made of all types of pollution: salinity, organic matter, suspended matter, and inorganic matter which acknowledge that their origin to be domestic, industrial and agriculture.

The wastewater discharged by industries processing fish seem the source of the salinity of treated water. This blocks the reuse of sludge/mud from the decanter and the malfunction of the process steps of the processing plant because of the solid waste and organic fish intake.

In conclusion, the process of the plant is effective to eliminate as much pollution. The quality of treated water obtained during five years since 2006 meets the discharge limits and requirements of the Ministry and the WHO standard except that the salinity is slightly higher in purified water to be destined for reuse in agriculture without constraint.

\section{Acknowledgments}

We present our thanks to the RAMSA (Régie Autonome Multiservices d'Agadir; Water Supply Service of Agadir) for their collaboration in the course of this work in good conditions at the site of the M'zar plant. We also thank the analysis laboratory (water, soil, and plant), the regional office of agricultural development in Marrakech which assesses the progress of this work.

\section{References}

Al-Hamaiedeh. H., \& Bino, M. (2010). Effect of treated grey water reuse in irrigation on soil and plants. Desalination, 256, 115-119. http://dx.doi.org/10.1016/j.desal.2010.02.004

Arnal, J. M., León, M. C., Lora, J., Gozálvez, J. M., Santafé, A., Sanz, D., \& Tena, J. (2008). Ultrafiltration as a pre-treatment of other membrane technologies in the reuse of textile wastewaters. Desalination, 221, 405-412. http://dx.doi.org/10.1016/j.desal.2007.01.099

Bali, M., Gueddari, M., \& Boukchina, R. (2010). Treatment of secondary wastewater effluents by infiltration percolation. Desalination, 258, 1-4. http://dx.doi.org/10.1016/j.desal.2010.03.041

Chang, D., \& Ma, Z. (2012). Wastewater reclamation and reuse in Beijing: Influence factors and policy implications. Desalination, 297, 72-78. http://dx.doi.org/10.1016/j.desal.2012.04.019

Hadadin, N., Qaqish, M., Akawwi, E., \& Bdour, A. (2010). Water shortage in Jordan -Sustainable solutions. Desalination, 250, 197-202. http://dx.doi.org/10.1016/j.desal.2009.01.026

Liu, Y., Yang, T., Yuan, D., \& Wu, X. (2010). Study of municipal wastewater treatment with oyster shell as biological aerated filter medium. Desalination, 254, 149-153. http://dx.doi.org/10.1016/j.desal.2009.12.003

Mouhanni, H., Bendou, A., \& Er-Raki, S. (2011). Disinfection of treated wastewater and reuse in irrigation of golf grass: the case of plant M'zar Agadir-Morocco. Water, 3, 1128-1138. http://dx.doi.org/10.3390/w3041128

Mouhanni, H., Hamdi, H., Bendou A., Cavalli, E., \& Benzine, L. (2012). Impact de la réutilisation des eaux usées épurées en irrigation: analyse ionique des lyxiviats. Sciences de l'Eau, 25, 69-73. Retrieved from http://id.erudit.org/iderudit/10.7202/1008536ar

Quevedo, N., Sanz, J., Lobo, A., Temprano, J., \& Tejero, I. (2012). Filtration demonstration plant as reverse osmosis pretreatment in an industrial water treatment plant. Desalination, 286, 49-55. http://dx.doi.org/10.1016/j.desal.2011.10.037

Rodier, S. J. (1996). Analyse de l'eau (8ème ed.). Paris.

Yi, L., Jiao, W., Chen, X., \& Chen, W. (2011). An overview of reclaimed water reuse in China. Journal of Environmental Sciences, 23, 1585-1593. http://dx.doi.org/10.1016/S1001-0742(10)60627-4

Zhang, X., Zhao, X., Zhang, M., \& Wu, Q. (2011). Safety evaluation of an artificial groundwater recharge system for reclaimed water reuse based on bioassays. Desalination, 281, 185-189. http://dx.doi.org/10.1016/j.desal.2011.07.060 
Zhao, F., Xi, S., Yang, X., Yang, W., Li, J., Gu, B., \& He, Z. (2012). Purifying eutrophic river waters with integrated floating island systems. Ecological Engineering, 40, 53-60. http://dx.doi.org/10.1016/j.ecoleng.2011.12.012 